\title{
Kuzbass Development Strategy: Past Lessons and Future Wrongs
}

\author{
Yuri Fridman ${ }^{1,2, *}$, Galina Rechko ${ }^{1,2}$, and Ekaterina Loginova ${ }^{1}$ \\ ${ }^{1}$ Institute of Economics and Industrial Engineering of the Siberian Branch of the Russian Academy of \\ Sciences, 630090 Novosibirsk, 17 Acad. Lavrentyev Av., Russian Federation \\ ${ }^{2}$ T.F. Gorbatchev Kuzbass State Technical University, 650000 Kemerovo, 28 Vesennya st., Russian \\ Federation
}

\begin{abstract}
The article discusses the place and role of strategic planning in ensuring that Kemerovo Oblast - Kuzbass develops comprehensively. For over thirty years, we have been studying the region with one of the leading national territorial-production centers established in the 20th century, how it emerged and functioned. Studies suggest that without regard to the economies of Russia as a whole and Kuzbass's neighboring regions in particular, its issues cannot be satisfactorily resolved. At large, when strategic planning followed this assumption, it contributed to how fast and holistically the territory developed. Considering that, in the 21st century, strategy makers diverged from this concept and started to search for new approaches, the region's economy has slowed down and its living standards have declined sharply. The momentum can be reversed with an active state socio-economic policy. Its previous forms, however, when the state gave preferences to private companies and did not require corresponding growth in standards of living in return, became unacceptable. It is necessary to work out a system of effective solutions and measures with mechanisms for reconciling the interests of the government, business and society within approaches that are adequate to the political and economic reality of today's world.
\end{abstract}

\section{Introduction}

The authors of this article have been analyzing the development of Kemerovo Oblast Kuzbass for more than thirty years. In the process, we have thoroughly studied the strategies, models, and plans that have and continue to define the economic structure, public policy priorities, main lines of growth for industries and business in Kemerovo Oblast since the early commercial extraction of the region's natural resources to the present day. We pay particular attention to the coal industry, which is the backbone for the Kuzbass economy. Today, the future of coal as an energy source is globally and extensively debated due to an array of economic, technological, political, and environmental reasons. Industry experts believe that the global energy system has entered a period of deep transformation, the so-called energy transition. This term, proposed by V. Smil, is used to describe "changes in the structure of primary energy consumption and the gradual transition from the existing energy supply scheme to a new state of the energy system" [1]. The current

\footnotetext{
${ }^{*}$ Corresponding author: yurifridman $@$ mail.ru
} 
energy transition is the fourth in a series of similar fundamental structural shifts in the global energy sector. However, unlike the previous three stages, the driver of change is now "not so much the economic attractiveness of new energy sources but a qualitatively new factor: decarbonization and the fight against global climate change" [2]. This means that the world's fuel and energy balance will continue to diversify towards unconventional renewable energy sources with the use of carbon-free or low-carbon technologies. Evidence suggests that the most drastic changes await coal and its role in the structure of the world's energy generation industry, where this type of fuel is most prevalent.

Russia is the third-largest exporter of coal in the global market. If a scenario of the world energy industry decarbonization takes (even partial) effect, it may not only have negative consequences for Russia's coal sector but also entail risks for the coal business, as it is purely export-driven. A decrease in global demand for coal turns out to be a strategic threat to Russian regions with coal-based economies. Kemerovo Oblast - Kuzbass, producing almost $60 \%$ of the country's coal, is at the most risk. No matter how scientifically grounded the positions of supporters and opponents of the global climate change theory are now, public consciousness all over the world is obviously tilting towards environmentalism - and this means the demand for clean energy sources will only be going up. There comes a need to revise state policy related to coal-mining areas; naturally, to accompany this change, the Russian government should adjust resource-rich regions' development models and employ functional tools to reach their strategic objectives. Looking at the history of the coal industry in Kuzbass, we sadly observe that strategic planning is quite ineffective when used to adapt the economy to the changing external environment.

\section{Materials and Methods}

The study of trends in Kuzbass development relied on examining official documents of strategic planning and statistical data, as well as the authors' original calculations with statistical analysis methods, among others. Let us consider specific examples. To estimate structural factors behind economic growth in Kemerovo Oblast, we turned to shift-share analysis, a quantitative technique used for assessing structural changes in the regional economy [3-7]. Then, in order to evaluate various directions that the coal cluster's innovative development paths may impact the competitiveness of the regional economy, we developed dedicated model-methodological constructions (see [8-9]). Thus, the conclusions and generalizations drawn from our comprehensive study of Kuzbass meet the requirements of validity and objectivity.

\section{Results and Discussion}

Over the past hundred years, Kuzbass has tested a wide range of development models with varying degrees of success. Below are notable milestones for Kemerovo Oblast.

The first strategic plan for regional development was bound to Kuznetsk Collieries JSC (known as "Kopikuz") first established in the 1910s with a significant equity interest held by French investors. Kopikuz operated in several fields: it studied the Kuznetsk Basin, built coal mines, designed and put into practice the idea of creating a coke plant and several other enterprises. All this can ultimately be considered as the first attempt to create coal industry value chains for mining and processing in Kuzbass.

Many of Kopikuz's ideas, including plans for a major fuel and energy sector, were implemented later during the Soviet times as part of a large-scale industrial cluster project in Kuzbass, which was intended to lay the groundwork for the whole country's accelerated 
development. In 1948, the city of Kemerovo hosted a scientific conference on the productive forces of Kuzbass. The recommendations formulated there have defined the strategy of the region's development for many years to come. Intending to support knowledge-intensive (for those times) and high-margin production, the Kuzbass authorities opened new industrial enterprises, established research and design institutes, developed training and retraining systems for workers of various qualifications. So, at the turn of the 1960 s, the length of value chains in Kemerovo Oblast increased to 5-7 links.

A side effect of such a development model was a slowly brewing social conflict as the region's industry strengthened. Male-dominated occupations prevailed in the region, employment was on the decline, environmental expenditures remained at zero, and lifesupport systems did not conform to accepted standards.

A turning point in strategic planning for Kemerovo Oblast was 1988. For the first time in history, the region-its authorities, academic community, and society-opposed the strategy proposed by the federal government, accusing it of draining the region of natural resources with no intent to improve living standards and quality of life, or to solve environmental problems. The unwillingness of the Center to change the "rules of the game" provoked a wave of miners' strikes, which led to some trade-offs between the federal and regional governments. In the brief but extremely important for Kuzbass's development historical period, it managed to obtain some contradictory yet very efficient tools such as a regional for-profit management model (1989), which inter alia implied a direct dependence of living standards on the results of economic development. Shortly after (1991) Kemerovo Oblast received a bonus opportunity of benefiting from the advantages of a free economic zone (FEZ) status. These models, by their nature, were not aimed at economic growth; they only allowed to "return" retrospectively a part of the rent withdrawn by the Center to the region at the expense of such ingenious mechanisms of the planned economy as an increase in financial transfers from the federal budget to the regional one for the purpose of covering new wages averages and a higher "social regional standard" expressed monetarily (classifying the region as a higher-level in terms of wages, raising standards of medical care and education, etc.). The result was that, within two years, the residents of Kuzbass became almost twice as wealthy as their neighbors, but artificially and only on paper. But as soon as regional authorities began to enforce the "prosperity funds" policy through the said tools, pro-profit models and assigning the FEZ status to the area, specialization industries that had already discussed privatization plans unilaterally withdrew from the existing agreements. It was the end of the regional for-profit model. The main industries in Kuzbass only saw growth prospects if they started to cooperate internationally and explored new markets. And yet, the region possessed a unique, in its way, leverage on the specialization industries. Thanks to the miners' strikes, Kuzbass (being a region in the middle of Russia) was declared a free economic zone.

It is unfortunate to say that of all the opportunities provided by the FEZ status, the region only managed to advance its foreign trade. Exports have greatly changed the Kuzbass' consumer face, while the use of coal and metal as a sort of currency for the supply of equipment from abroad has enabled several major investment programs to modernize the region's agribusiness, renovate the airports in Kemerovo and Novokuznetsk, and boost road construction. Still, when Kuzbass "got on in the world" and entered the international market, it vividly showed how much the economy of Kemerovo Oblast lagged in terms of technology and how fragile its competitive advantages were.

The first half of the 1990s (until 1996) became for Kemerovo Oblast a period of economic deindustrialization; the region abandoned previously adopted strategic plans almost entirely. At the same time, it experimented with various other development paradigms suitable for Kuzbass. The following features gave shape to the new model: denationalization of basic industries, a strong influence of international institutions on a 
concept of coal industry privatization, trust in a self-regulating market. During this period, the state withdrew from all primary branches of the Kuzbass economy, and the strategy of regional development quickly devolved to siphoning natural resources and raw materials away, further environmental degradation, and rapidly growing social unrest. It also became clear that market mechanisms alone would not bring the interests of business and society into harmony.

The situation started to change drastically with a new administrative team headed by Aman Tuleev coming to Kuzbass (1997). Strategic planning focused on finding models to carry out a new paradigm of regional development. It possessed the following features: coal industry restructuring and its growth through export development were taken as a basis of the Kuzbass economy; only socially responsible proprietors, who could reach an agreement on "additional contribution" to the region's development with the government, were allowed, so to speak, to own assets in Kuzbass; the territory and "other" economies, including the one concerned with knowledge (science, medicine, education, etc.), and small business were not considered priorities; the regional budget was a social institution (not a development tool!) with the main purpose of bringing social stability to the region.

The authors of the Program for Social and Economic Development of Kemerovo Oblast for the period 2005-2010 did not understand the new team's economic ideas. They still acted on the premise that Kuzbass was not a socio-economic structure highly capable of fitting into global value chains but merely a "production site" of the Russian economy. Contrary to the government's wishes, they saw no need to integrate Kuzbass into the world economy - a strategic blunder, indeed. As a consequence, the program quickly fell into oblivion at a time when the living standards were on the rise, supported by growing investments in coal mining and high prices on world commodity markets, and housing construction was flourishing.

But we should not forget that an open economy brings both new markets and financial, price crises. Here Kuzbass encountered a new phenomenon. Owing to such universal manifestations of economic globalization as aggravating interregional/international competition and falling prices for primary Kuzbass export products, its economic growth slowed down substantially. It all became clear: the region needs new growth drivers. The new Kuzbass development program (for the period 2007-2012) and development strategy (till 2025) hypothetically submerged the region into the outside world and evaluated its export potential. Kemerovo Oblast experienced a peculiar change of perspective and prospects for further development. The 2005-2010 Program implied a search for a "launching pad" for the region's development by upgrading the basic components of its socio-economic system to modern standards, with regard to the interests of local business, and using the existing experience. In contrast, the 2007-2012 Program and 2025 Strategy called for trying some new, potentially successful practices. The altered approach to defining risks and development priorities in Kuzbass reflects the changes experienced by the regional authorities in the 2000s regarding their vision of the future of Kemerovo Oblast and search directions for a new regional economic model. However, the authors of the 2025 Strategy have also made a few miscalculations. For one, despite talks of a "resource curse" in Russia, the need to diversify the economy and introduce innovations, they urged the government and business to increase the coal-to-coke conversion ratio, improve relevant production facilities and offer high-margin products when entering markets. As a result, a great amount of resources was allocated to promote a new coal chemical cluster in Kuzbass and other projects that, given the lack of necessary expertise in the region, support from large businesses and, importantly, market demand for such products, have never seen the light of day. From the standpoint of strategic planning quality, the 2025 Strategy is a document which, we believe, will be a source of ideas for the future development of Kuzbass for many years to come. But no more than that, as it does not provide an answer to 
the central question: how to actually launch the implementation of regional development plans, what mechanisms are needed to reconcile the interests of both business and society.

After the shift of power in 2018, Kemerovo Oblast formulated and adopted the Strategy for Social and Economic Development until 2035. The main declared growth drivers for the region were the reindustrialization policy, accelerated development rates, and ubiquitous clustering. Additionally, the Strategy announced a "two-year leap" (2018-2019) concept. According to its authors, Kuzbass must become one of the leading territories in terms of development and living standards, right after the Ural Federal District. Out of several proposed development options, the authors of the 2035 Strategy consider the target scenario most realistic and preferable for ensuring breakthrough economic growth in Kuzbass, which implies structural modernization through reforming basic processes in the economy and management. It involves, among other things, a systemic transformation of the region's economy and socio-cultural space, prioritizing high-tech industries, government support for investment projects, etc. The authors of the strategy believe that this scenario is able to solve such critical issues as providing high living standards, making the Kuzbass economy more resistant to cyclical fluctuations in the world commodity markets, and imposing stricter environmental regulations on mining activities. The 2035 Strategy reflects the aspiration of the current Kuzbass authorities to form a workable mechanism for reconciling the interests of its residents and businesses, as well as actively involve all available internal and external resources in the development of the region.

We see that all the strategic documents of Kemerovo Oblast covering the last two decades contain a rather in-depth analysis of the socio-economic sphere and environmental situation in the region at the time of their drafting. They explore regional competitive strengths, set ambitious goals for economic growth, people's living standards, and tackling environmental issues. However, unlike the strategic plans of the first half of the 20th century, these strategies have all failed (and there are reasons to believe the same fate will befall the 2035 one) since their creators had not recognized the multi-level nature of development problems in Kuzbass.

The structure of the Kuzbass economy that emerged in the USSR turned out to be very stable and its "inherited" features continue to determine the dynamics of the region's economic development.

Although the goals of economic diversification are declared in strategic documents, any more or less coherent attempts to achieve them, even involving the government, do not yield the desired result. Economic modernization in Kemerovo Oblast is slow, with more than a third of the region's gross value-added coming from coal production. The region sits on the margins of all-Russian development trends. There is no understanding of how interregional relations work, which naturally raises the question if Kuzbass is at all ready to come face to face with global challenges.

\section{Conclusion}

The strategic development of Kemerovo Oblast - Kuzbass is a complex, multi-level problem. We believe it stems from the fact that since the onset of commercial exploitation of coal deposits, the authorities (and the authors of strategies contracted by authorities at various tiers of government) have regarded Kuzbass merely as a "production unit". During the Soviet period and its planned state-controlled economy, it fitted into the general context of the country's development, which ultimately conditioned the region's industrial specialization. After the USSR collapsed and the coal industry was privatized, Kuzbass virtually became a business unit just within the development of individual corporations focusing primarily on raw materials. It was at that time that the region turned into a center of primary redistribution and primitive manufacturing chains, although the formerly added 
value of final products in Kemerovo Oblast had been 17 to 20 times higher than the cost of raw materials. This happened in light of the country's atomization and weakening of interregional ties.

All the while, Kemerovo Oblast was off out of the state and corporate strategists' radars as a "territory with a unique natural and human resource package". Such an approach makes the region extremely vulnerable. While it is precisely by using their "resource packages" that regions can adapt to changes in the external environment, as proven worldwide. We believe the momentum can be reversed with an active state socio-economic policy. Its previous forms, however, when the state gave preferences to private companies and did not require corresponding growth in standards of living in return, became unacceptable. It is necessary to work out a system of effective solutions and measures with mechanisms for reconciling the interests of the government, business and society within approaches that are adequate to the political and economic reality of today's world [10-15].

\section{Acknowledgement}

The publication is prepared within the priority XI.174. (project No. XI.174.1.1. "Economy of Siberia and its Regions Among the External and Internal Challenges and Threats: Methodology, Trends, Forecasts", No. AAAA-A17 117022250133-9) according to the research plan of the IEIE SB RAS.

\section{References}

1. V. Smil, Energy Transitions: History, Requirements, Prospects (Praeger, Santa Barbara, 2010)

2. A.A. Makarov, T.A. Mitrova, V.A. Kulagin, Global and Russian Energy Outlook 2019 (ERI RAS - MSM Skolkovo, Moscow, 2019)

3. J. Esteban, Reg. Sci. Urban. Econ., 30, 353 (2000)

4. H. W. Herzog, R. J. Olsen, J. Regional. Sci., 19, 393 (1979)

5. D. C. Knudsen, Socio. Econ. Plan. Sci., 34, 177 (2000)

6. H. W. Richardson, Int. Regional. Sci. Rev., 3, 1 (1978)

7. Iu. A. Fridman, G. N. Rechko, Probl. Econ. Transit., 55, 30 (2012)

8. Yu. Fridman, G. Rechko, E. Loginova, J. Min. Sci+, 51, 924 (2015)

9. Yu. Fridman, G. Rechko, A. Pimonov, Reg. Res. Russ., 7, 333 (2017)

10. V. Kryukov, A. Sevastyanova, A. Tokarev, V. Shmat, Econ. Reg., 13, 93 (2017)

11. Y. Fridman, E. Loginova, G. Rechko, E3S Web of Conferences, 134, 03002 (2019)

12. S. Ville, O. Wicken, Ind. Corp. Change, 22, 1341 (2013)

13. V. Kondrat"ev, World Economy Int. Relat., 60, 41 (2016)

14. V. V. Kuleshov, V. E. Seliverstov, Reg. Res. Russ., 8, 345 (2018)

15. V. E. Seliverstov, L. V. Melnikova, E. A. Kolomak, V. A. Kryukov, V. I. Suslov, N. I. Suslov, Reg. Res. Russ., 9, 155 (2019) 